\title{
PENGARUH MODEL PEMBELAJARAN KOOPERATIF TIPE STAD TERHADAP HASIL BELAJAR SISWA PADA MATERI LISTRIK DINAMIS SEMESTER II KELAS X SMA NEGERI 1 RANTAU SELATAN T.P 2013/2014
}

\author{
Siti Zaitun Hsb dan Abd. Hakim S \\ za_0610@yahoo.co.id \\ Jurusan Fisika FMIPA Universitas Negeri Medan \\ Jalan Willem Iskandar Pasar V Medan, 20221
}

\begin{abstract}
This study aims to determine the significant effect of the result cooperative learning model to the student's learning result in the main subject second semester X "Dynamic Power" Class in SMA Negeri 1 Rantau Selatan T.P 2013/2014. This research is quasi experimental. The population in this research was all students in class $\mathrm{X}$ which consists of 10 classes. With random cluster sampling technique was chosen class X-2 and $\mathrm{X}-1$ as an experimental class and control class. Instrument were contain of multiple-choice tests and observation sheet test have been conducted to measure the student's learning outcames. Research's design is Control Group Pretest-Postest Design. Average data of pre-test experimental class and control class was 47.5 and 51.56. In both classes of the test data obtained pretest that both classes of data are normally distributed and homogeneous. T-test result of pretest obtained $t<t$ table $0,04<1.99$, then Ho is accepted means the ability of the students at the beginning of the second class of the same. Then given treatment that is experimental class with cooperative learning model STAD and a control class with conventional learning models. The posttest average yield experimental class and control class is 70.5 dan 61.5 . In both classes of the test data obtained posttest that both classes of data are normally distributed and homogeneous. T test results obtained $t>t$ table 3.09 $>1.99$ then the $\mathrm{Ha}$ was accepted that no significant influence cooperative learning model STAD to the student learning outcomes.
\end{abstract}

Keywords : Cooperative type STAD, activity, learning results

\section{PENDAHULUAN}

Pendidikan adalah salah satu bentuk perwujudan kebudayaan manusia yang dinamis dan sarat perkembangan. Oleh karena itu, perubahan atau perkembangan pendidikan adalah hal yang memang seharusnya terjadi sejalan dengan perubahan budaya kehidupan. Peubahan dalam arti perbaikan pendidikan pada semua tingkat perlu terus menerus dilakukan sebagai antisipasi kepentingan masa depan.

Pendidikan yang mampu mendukung pembangunan di masa mendatang adalah pendidikan yang mampu mengembangkan potensi peserta didik, sehingga yang bersangkutan mampu menghadapi dan memecahkan problema 
kehidupan yang dihadapinya. Pendidikan harus menyentuh potensi nurani maupunn potensi kompetensi peserta didik. Konsep pendidikan tersebut terasa semakin penting ketika seseorang harus memasuki kehidupan di masyarakat dan dunia kerja, karena yang bersangkutan harus mampu menerapkan apa yang dipelajari di sekolah untuk menghadapi problema yang dihadapi dalam kehidupan sehari-hari saat ini maupun yang akan datang.

Ilmu fisika sebagai salah satu bidang kajian Ilmu Pengetahuan Alam sudah diperkenalkan sejak dini kepada siswa, mulai dari SD hingga ke jenjang yang lebih tinggi dan sudah termasuk salah satu mata pelajaran yang diujikan di ujian nasional (UN). Fisika sebagai sebuah produk karena terdiri dari sekumpulan pengetahuan yang berupa fakta-fakta, konsep-konsep, prinsip dan hukum tentang gejala alam. Fisika sebagai sebuah proses, karena merupakan suatu rangkaian kegiatan yang terstruktur dan sistematis yang dilakukan untuk menemukan konsep, prinsip dan hukum tentang gejala alam termasuk di dalamnya adalah kemampuan berpikir untuk menyusun dan menemukan konsepkonsep baru. Sedangkan fisika sebagai suatu sikap, karena diharapkan mampu menimbulkan karakter bagi siswa sesuai dengan nilai siswa.

Rendahnya hasil belajar merupakan masalah dalam proses pembelajaran fisika. Berdasarkan hasil studi pendahuluan yang dilakukan di SMA Negeri 1 Rantau Selatan Kabupaten Labuhan Batu, hasil ulangan harian siswa menunjukkan bahwa untuk mata pelajaran Fisika, sekitar $67 \%$ siswa
SMA mendapatkan nilai di bawah KKM atau kurang dari 65. Sehingga dapat dikatakan pencapaian hasil fisika tergolong masih rendah dan tidak mencapai standar yang diharapkan.

Berbicara tentang rendahnya mutu pendidikan di Indonesia berkaitan erat dengan bagaimana proses belajar mengajar yang dilakukan di sekolah. Guru cenderung menggunakan metode ceramah sehingga anak didik merasa bosan dan malas belajar. Proses belajar mengajar merupakan interaksi yang dilakukan antara guru dan siswa dalam situasi pendidikan untuk mencapai tujuan yang ditetapkan

Berdasarkan hasil wawancara yang dilakukan dengan guru dan siswa SMA Negeri 1 Rantau Selatan, ada beberapa faktor yang mempengaruhi hasil belajar antara lain dari pihak pengajar, pihak siswa, sarana dan prasarana serta lingkungan. Penyebab rendahnya hasil belajar fisika di sekolah tersebut adalah: (1) Guru yang mengajar di sekolah itu menggunakan metode ceramah (2) Siswa lebih sering mencatat apa yang diajarkan oleh guru yang di tulis di papan tulis (3) siswa jarang sekali memberi pendapatnya terhadap pelajaran yang diajarkan oleh guru (4) kegiatan pembelajaran yang belum bervariasi menyebabkan peserta didik merasa kebutuhan belajarnya belum terpenuhi. (5) Siswa lebih sering belajar secara individual.

Permasalahan tersebut dapat diupayakan pemecahannya yaitu dengan melakukan tindakantindakan yang dapat mengubah suasana pembelajaran konvensional yang berpusat pada guru sehingga 
menghadapkannya pada pembelajaran kooperatif yang berpusat pada siswa. Pembelajaran kooperatif merupakan suatu sikap bekerja diantara sesama dalam bentuk kerja kelompok, dimana tiap kelompok terdiri dari 2 orang atau lebih yang keberhasilannya dipengaruhi oleh keterlibatan setiap anggota kelompok. Pembelajaran kooperatif adalah model pembelajaran yang mengetengahkan realita kehidupan yang dirasakan dan dialami oleh siswa dalam kehidupan sehari-harinya dengan bentuk yang disederhanakan di dalam kelas.

Model pembelajaran kooperatif ini merupakan model pembelajaran yang dikembangkan atas dasar teori bahwa siswa akan lebih mudah menemukan dan memahami konsep yang sulit apabila siswa dapat mendiskusikan masalah itu dengan teman.

STAD merupakan salah satu tipe dari model pembelajaran kooperatif yang paling sederhana dimana siswa dikelompokkan menjadi beberapa kelompok dengan anggota empat sampai lima orang, dan setiap kelompok harus heterogen. Tipe ini dikembangkan oleh Slavin, tipe ini merupakan salah satu tipe kooperatif yang menekankan pada adanya aktivitas dan interaksi diantara siswa untuk saling memotivasi dan saling membantu dalam menguasai materi pelajaran guna mencapai prestasi yang maksimal (Isjoni, 2009: 51).

\section{METODE PENELITIAN}

\section{A. Hasil Penelitian}

Penelitian ini dilaksanakan di SMA Negeri 1 Rantau Selatan pada semester II T.P 2013/2014. Penelitian ini melibatkan dua kelas yang diberi perlakuan berbeda. Kelas eksperimen menggunakan model pembelajaran koperatif tipe STAD sedangkan di kelas kontrol menggunakan pembelajaran konvensional. Untuk mengetahui hasil belajar fisika siswa dilakukan dengan memberikan tes pada kedua kelas sebelum dan sesudah diberi perlakuan.

Instrumen yang digunakan adalah tes hasil belajar siswa dan observasi aktivitas siswa. Tes hasil belajar siswa berjumlah lima belas (15) soal dalam bentuk pilihan berganda dengan empat pilihan yaitu $\mathrm{a}, \mathrm{b}, \mathrm{c}$, dan d. tes ini diberikan sebanyak 2 kali yaitu pada saat pretes dan postes. Sedangkan observasi yang dimaksud dalam penelitian ini adalah observasi yang dilakukan untuk mengamati keseluruhan aktivitas belajar siswa selama pelaksanaan proses pembelajaran.

Desain penelitian yang digunakan adalah desain Control Group Pretest-Posttest Design. Desain penelitian ini ditunjukkan pada Tabel 1.

Tabel 1. Control Group PretestPosttest Design

\begin{tabular}{|c|c|c|c|}
\hline Kelas & Pretes & $\begin{array}{c}\text { Perlakua } \\
\mathrm{n}\end{array}$ & Postes \\
\hline Eksperimen & $\mathrm{Y}_{1}$ & $X_{1}$ & $\mathrm{Y}_{2}$ \\
Kontrol & $\mathrm{Y}_{1}$ & $X_{2}$ & $\mathrm{Y}_{2}$ \\
\hline
\end{tabular}

Keterangan :

$\mathrm{X}_{1}=$ model pembelajaran STAD

$\mathrm{X}_{2}=$ model konvensional

$\mathrm{T}_{1}=$ Pemberian pretes

$\mathrm{T}_{2}=$ Pemberian postes

Uji Lilliefors digunakan untuk mengetahui data kedua sampel beristribusi normal. Uji homogenitas digunakan untuk mengetahui apakah kedua sampel berasal dari 
populasi yang homogen. Uji homogenitas menggunakan uji hipotesis.

Pengujian hipotesis digunakan uji $t$ dengan rumus :

$$
t=\frac{\overline{x_{1}}-\overline{x_{2}}}{S \sqrt{\frac{1}{n_{1}}+\frac{1}{n_{2}}}}
$$

Dimana $\mathrm{S}$ adalah varians gabungan yang dihitung dengan rumus :

$$
\mathrm{S}^{2}=\frac{\left(n_{1}-1\right) S_{1}{ }^{2}+\left(n_{2}-1\right) S_{2}{ }^{2}}{n_{1}+n_{2}-2}
$$

Dengan: $t=$ distribusi $t$

$\overline{x_{1}}=$ Nilai rata-rata kelas eksperimen

$\overline{x_{2}}=$ Nilai rata-rata kelas kontrol

$\mathrm{n}_{1}=$ Ukuran kelas eksperimen

$\mathrm{n}_{2}=$ Ukuran kelas kontrol

$\mathrm{S}_{1}{ }^{2}=$ Varians kelas eksperimen

$\mathrm{S}_{2}{ }^{2}=$ Varian kelas kontrol

Kriteria pengujian adalah: terima $\mathrm{H}_{0}$ jika $t \geq t_{1-\alpha}$ dimana $t_{1-\alpha}$ didapat dari daftar distribusi $t$ dengan peluang (1a) dan $d k=n_{1}+n_{2}-2$ dan $\alpha=0,05$. Untuk harga $t$ lainnya $\mathrm{H}_{\mathrm{o}}$ ditolak. Validitas yang digunakan adalah validitas isi. Instrumen yang telah disusun divaliditaskan oleh dua orang dosen fisika dan satu guru fisika

\section{HASIL DAN PEMBAHASAN}

Penelitian ini termasuk jenis penelitian quasi experiment yang melibatkan dua kelas yang diberi model pembelajaran yang berbeda yaitu pada kelas eksperimen menggunakan model pembelajaran STAD dan pada kelas kontrol menggunakan pembelajaran konvensional. Sebelum kedua kelas diberikan perlakuan yang berbeda, kedua kelas terlebih dahulu diberikan pretes yang bertujuan untuk mengetahui kemampuan awal siswa. Berdasarkan hasil pretes yang diperoleh, nilai rata-rata pretes kelas eksperimen 47,5 dan nilai pretes kelas kontrol 51,56. Selanjutnya kelas eksperimen dan kelas kontrol diberikan perlakuan yang berbeda.

Kelas

eksperimen menggunakan model pembelajaran STAD dan pada kelas kontrol menggunakan pembelajaran konvensional. Setelah kedua kelas diberi perlakuan, masing-masing kelas diberi postes untuk melihat adanya perbedaan akibat diberikan perlakuan pembelajaran yang berbeda. Dari data postes kedua kelas diperoleh nilai rata-rata postes untuk kelas eksperimen sebesar 74,53 dan nilai rata-rata postes kelas kontrol sebesar 68,59. Hasil ini menunjukkan adanya perbedaan antara nilai postes kelas eksperimen dengan kelas kontrol

Berdasarkan hasil uji normalitas dengan menggunakan uji Lillliefors untuk kedua sampel diperoleh bahwa nilai pretes dan postes berdistribusi normal seperti ditunjukkan pada Tabel 2.

Tabel 2. Hasil Uji Normalitas Data

\begin{tabular}{|c|c|c|c|}
\hline \multirow{2}{*}{ Kelas } & \multicolumn{2}{|c|}{ Pretes } & \multirow{2}{*}{$\begin{array}{l}\text { Kesimpula } \\
\mathrm{n}\end{array}$} \\
\hline & Lhitung & Ltabel & \\
\hline $\begin{array}{l}\text { Eksper } \\
\text { i-men }\end{array}$ & $\begin{array}{c}0,112 \\
3 \\
\end{array}$ & \multirow{2}{*}{0,1400} & \multirow{2}{*}{ Normal } \\
\hline \multirow[t]{3}{*}{ Kontrol } & $\begin{array}{c}0,101 \\
8 \\
\end{array}$ & & \\
\hline & \multicolumn{2}{|c|}{ Postes } & \\
\hline & Lhitung & $\mathrm{L}_{\text {tabel }}$ & \\
\hline $\begin{array}{l}\text { Ekspri } \\
\text { men }\end{array}$ & $\begin{array}{l}0,096 \\
9 \\
\end{array}$ & \multirow{2}{*}{0,1400} & \multirow{2}{*}{ Normal } \\
\hline Kontrol & $\begin{array}{l}0,097 \\
4 \\
\end{array}$ & & \\
\hline
\end{tabular}
Pretes \& Postes Kedua Kelas

Pengujian homogenitas data pretes pada kelas eksperimen dan kelas kontrol dilakukan dengan uji t 
dua pihak untuk mengetahui apakah kelompok sampel berasal dari populasi yang homogen atau tidak.

Tabel 3. Hasil Uji Hipotesis Kelas

Eksperimen dan Kelas Kontrol

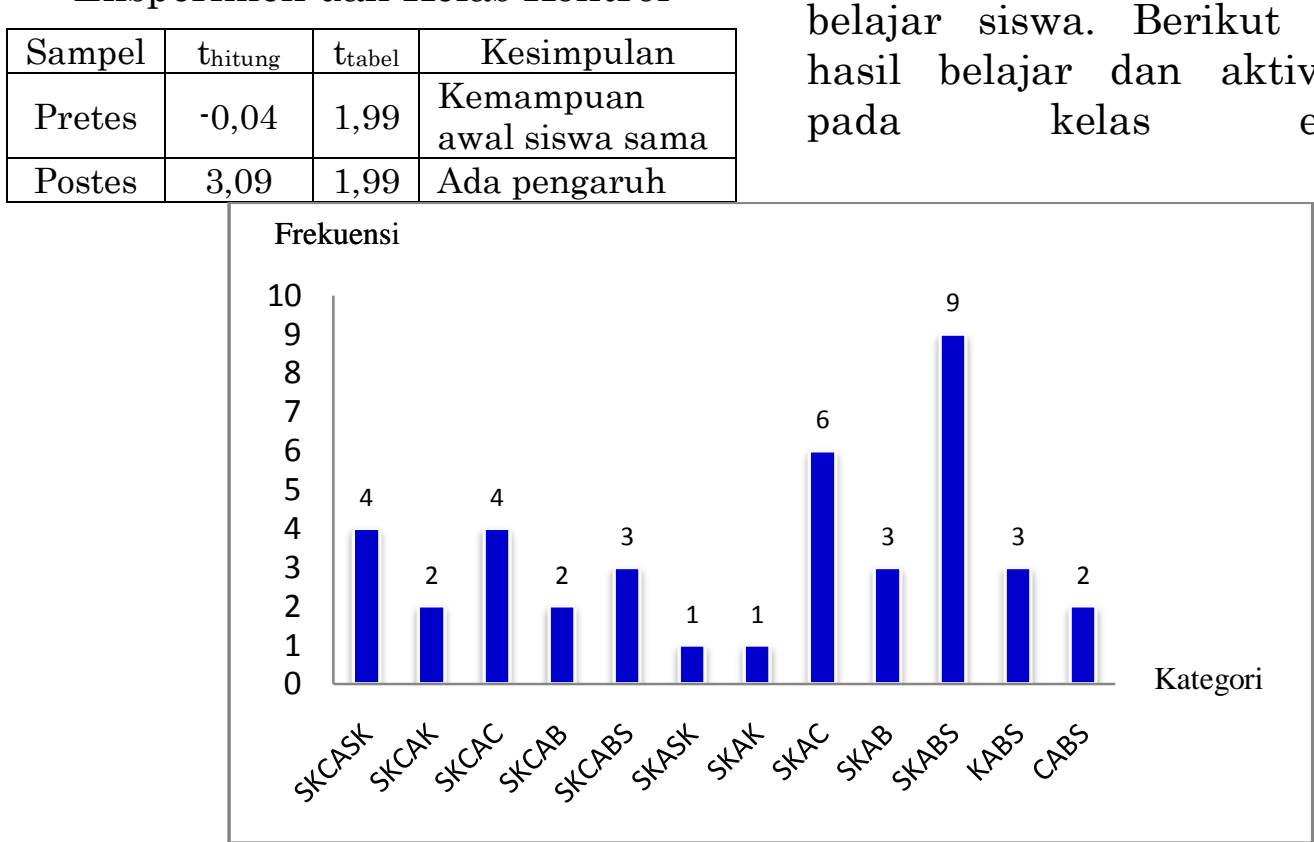

Gambar 1. Diagram batang kategori nilai pretes, aktivitas, postes
Keterangan dari gambara sebagai berikut: SKCASK (sangat kurang, cukup aktif dan sangat kurang), SKCAK (sangat kurang, cukup aktif dan kurang), SKCAC (sangat kurang, cukup aktif dan cukup), SKAK (sangat kurang, aktif dan kurang), SKCAB (sangat kurang, cukup aktif dan baik), SKCABS (sangat kurang, cukup aktif dan baik sekali), SKASK(sangat kurang,aktif sekali dan kurang), SKAC (sangat kurang, aktif dan cukup) , SKAB (sangat kurang, aktif dan baik), SKABS (sangat kurang,aktif dan baik sekali), KABS (kurang, aktif dan baik sekali), CAB (cukup, aktif dan baik sekali)

Aspek aktivitas yang dinilai antara lain, mengerjakan tugas kelompok yang diberikan, mengajukan pertanyaan, memberikan pendapat untuk
Berdasarkan Tabel 3, didapat $t_{\text {hitung }}>t_{\text {tabel }}$ dapat disimpulkan bahwa ada pengaruh yang signifikan akibat penerapan model pembelajaran STAD terhadap hasil belajar siswa. Berikut ini adalah hasil belajar dan aktivitas siswa pada kelas eksperimen. menyelesaikan masalah, memberikan tanggapan terhadap jawaban orang lain, mencatat hasil diskusi.

Data nilai pretes siswa berdasarkan nilai aktivitas terendah sampai tertinggi dapat dilihat pada Gambar 2.

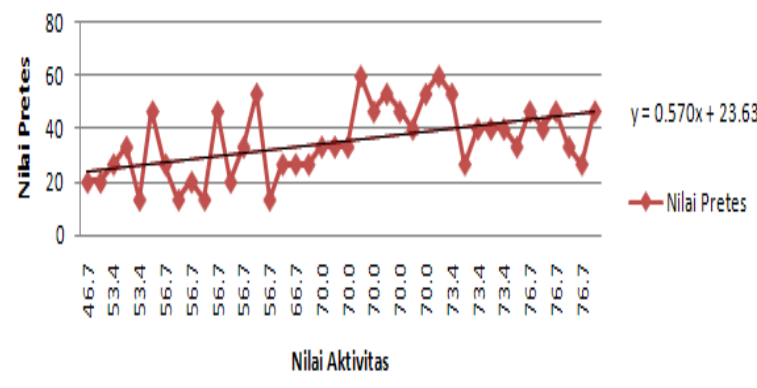

Gambar2. Grafik nilai Pretes siswwa berdasarkan nilaia aktivitas terendah sampai tertinggi

Gambar 2. diperoleh dengan menggunakan program Microsoft Office Exel 2007. Grafik Nilai Pretes terhadap aktivitas dengan nilai pretes dan aktivitas terendah 
13,3 dan 46.7 dan nilai pretes dan aktivitas tertinngi 60 dan 76,7. Persamaan linier $y=a x+b$ memiliki nilai a yang menyatakan kemiringan garis $y_{\text {pre }}=0,570 \mathrm{x}+$ 23,63. dengan nilai $\mathrm{R}=0.49$. maka dilihat dari persamaan garis nilai a maka aktivitas mempengaruhi hasil belajar dengan persentase 49 $\%$.

Berikut grafik nilai nilai Postes siswa berdasarkan nilai aktivitas terendah sampai tertinggi.

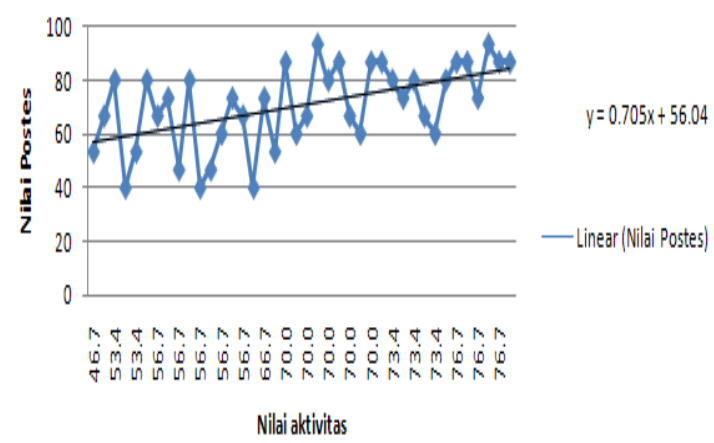

Gambar3. Grafik nulail Postes siswa berdasarkan wilai aktivitas terendah sampai tetinggi.

Gambar 3. diperoleh dengan menggunakan program Microsoft Office Exel 2007. Grafik Nilai Postes terhadap aktivitas dengan nilai postes dan aktivitas terendah 40 dan 46.7 dan nilai postes dan aktivitas tertinngi 93,3 dan 76,7. Persamaan linier $y=a x+b$ memiliki nilai a yang menyatakan kemiringan garis. $y_{\text {pre }}=0,705 \mathrm{x}+$ 56,04 dengan nilai $\mathrm{R}=0.53$. maka dilihat dari persamaan garis nilai a maka aktivitas mempengaruhi hasil belajar dengan persentase 53 $\%$.

Berikut adalah grafik nilai pretes siswa terhadap nilai aktivitas sesuai kelompok siswa.

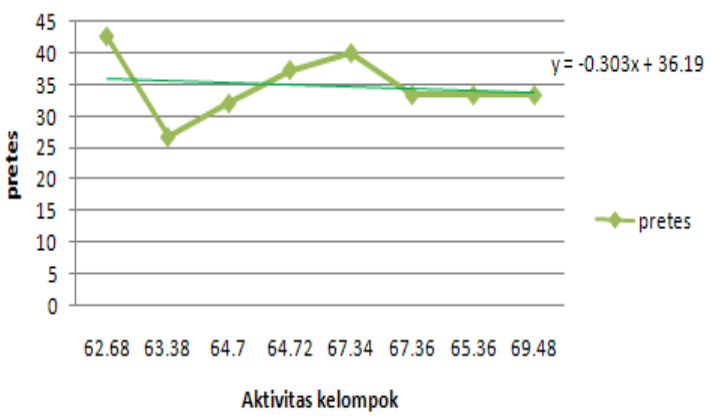

Gambar 4. Grafik Nilai Pretes Terhadap Nilai Aktivitas Kelompok

Gambar 4. diperoleh dengan menggunakan program Microsoft Office Exel 2007. Grafik Nilai Pretes berdasarkan kelompok terhadap aktivitas dengan nilai rata-rata pretes kelompok dan aktivitas kelompok terendah 26,67 dan 62,68 dan nilai rata-rata pretes kelompok dan aktivitas tertinngi 40 dan 69,48. Persamaan linier $y=a x+b$ memiliki nilai a yang menyatakan kemiringan garis. $y_{\text {preK }}=-0,303 x+$ 36,19 dengan nilai $\mathrm{R}=0.14$ maka dilihat dari persamaan garis nilai $a$ negatif maka aktivitas tidak mempengaruhi $14 \%$.

Berikut adalah grafik nilai postes siswa terhadap nilai aktivitas sesuai kelompok siswa.

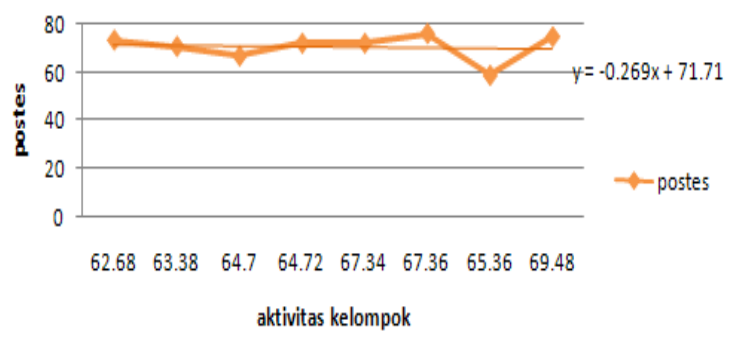

Gambar 5. Grafik Nilai Postes Terhadap Nilai Aktivitas Kelompok

Gambar 5. diperoleh dengan menggunakan program Microsoft Office Exel 2007. Grafik Nilai Postes berdasarkan kelompok terhadap aktivitas dengan nilai rata-rata postes kelompok dan aktivitas kelompok terendah 73,32 dan 62,68 dan nilai rat-rata postes kelompok dan aktivitas kelompok 
tertinngi 76 dan 76,7. Persamaan linier $y=a x+b \quad$ memiliki nilai $a$ yang menyatakan kemiringan garis. $y_{\text {pre }}=-269 x+7171$ dengan nilai $R=0,37$ maka dilihat dari persamaan garis nilai a negatif maka aktivitas tidak mempengaruhi dengan persentase $37 \%$

Berdasarkan hasil penelitian, nilai aktivitas tidak begitu mempengaruhi hasil belajar, nilai aktivitas siswa tidak secara keseluruhan memberikan sumbangan bagi peningkatan hasil belajar siswa.Walaupun secara umum rata-rata nilai keseluruhan aktivitas belajar siswa adalah 65,08 termasuk dalam kriteria aktif sejalan dengan kriteria kemampuan siswa juga dikriteriakan baik yaitu dengan nilai rata-rata postes 70,50 tetapi dilihat dari hasil persiswa hanya sebagian siswa dengan kriteria aktif yang mampu meningkatkan hasil belajarnya menjadi baik. aktivitas tidak mempengaruhi hasil belajar (nilai postes).

\section{B. Pembahasan}

Nilai aktivitas siswa tidak secara keseluruhan memberikan sumbangan bagi peningkatan hasil belajar siswa.Walaupun secara umum rata-rata nilai keseluruhan aktivitas belajar siswa adalah 65,08 termasuk dalam kriteria aktif sejalan dengan kriteria kemampuan siswa juga dikriteriakan baik yaitu dengan nilai rata-rata postes 70,50 tetapi dilihat dari hasil persiswa hanya sebagian siswa dengan kriteria aktif yang mampu meningkatkan hasil belajarnya menjadi baik. Hal ini dapat terjadi karena kelemahan yang terdapat dari penelitian.
Walaupun penggunaan model pembelajaran STAD dapat meningkatkan hasil belajar siswa, tetapi selama pembelajaran masih ada kendala yang dihadapi peneliti yaitu, ketika memberikan contoh pertanyaan yang cocok diberikan pada siswa saat proses pembelajaran berlangsung. Hasil penilaian aktivitas belum dapat memberikan gambaran meningkatkan hasil belajar seperti yang diharapkan, dalam hal ini kelemahan yang terjadi dapat disebabkan oleh penguasaan kelas yang belum maksimal dan juga penjelasan peneliti yang kurang memadai kepada observer.

Selain itu, kesulitan yang mengenai jam pembelajaran dan alokasi waktu dalam melakukan kerja kelompok. Hal ini dapat terjadi karena kelemahan peneliti dalam pembagian kelompok pada kelas eksperimen yang mungkin kurang heterogen.

Kurang terbiasanya siswa menggunakan model ini sehingga peneliti memerlukan banyak waktu dalam menjelaskan apa yang harus dilakukan siswa saat proses pembelajaran berlangsung. Namun pelaksanaan model pembelajaran STAD dapat berjalan baik dilihat dari nilai rata-rata postes $>$ nilai rata-rata pretes.

Penelitian ini didukung oleh hasil penelitian terdahulu yang telah dilakukan oleh Rusaidi, FMIPA Universitas Negeri Medan, dengan judul skripsi Pengaruh Model pembelajaran kooperatif tipe STAD terhadap hasil belajar siswa pada materi pokok energi kelas VIII semester II SMP Swasta Madya utama medan T.A. 2008/2009, hasil dari penelitian beliau adalah Ada perbedaan yang signifikan antara 
hasil belajar fisika menggunakan model pembelajaran kooperatif tipe STAD dengan kelas yang tidak menggunakan model pembelajaran kooperatif tipe STAD

\section{KESIMPULAN DAN SARAN Kesimpulan}

Berdasarkan hasil penelitian, penulis mengemukakan kesimpulan sebagai berikut: (1) Hasil belajar siswa dengan menggunakan model pembelajaran kooperatif tepe STAD khususnya pada materi listrik dinamis memberikan nilai rata-rata dengan kategori baik dan aktif (2) Hasil belajar siswa dengan menggunakan pembelajaran konvensional khususnya pada materi perpindahan listrik dinamis memberikan nilai rata-rata dengan kategori cukup dan aktif (3) Aktivitas siswa yang dikembangkan dari model pembelajaran kooperatif tipe STAD memberi informasi bahwa dapat meningkatkan keaktifan siswa dalam proses pembelajaran ditinjau dari hasil rata-rata aktivitas disetiap pertemuan dinyatakan dengan kategori aktif. (5) Ada perbedaan yang signifikan akibat pengaruh model pembelajaran kooperatif tipe STAD terhadap hasil belajar siswa pada materi listrik dinamis black di kelas X semester II SMA Negeri 1 Rantau Selatan T.P 2013/2014.

\section{Saran}

Berdasarkan hasil penelitian dan kesimpulan di atas, sebagai tindak lanjut dari penelitian ini disarankan beberapa hal sebagai berikut: (1) Masih Banyak pembenahan dalam penyusunan instrumen soal (2) Masih perlu pembenahan aktivitas dalam implementasi model pembelajaran kooperatife tipe STAD.

\section{DAFTAR PUSTAKA}

Arends., (2008), Learning To Teach, Belajar Untuk Mengajar Jilid 2, Penerbit Pustaka Belajar, Yogyakarta

Arikunto, S., (2009), Dasar-Dasar Evaluasi Pendidikan, Penerbit PT. Bumi Aksara, Jakarta

Djamarah.B.S, Aswan Zain, 2006, Strategi Belajar Mengajar, Rineka Cipta,Jakarta

Isjoni, (2010), Cooperative Learning, Alphabeta, Bandung

Istarani, (2011), 58 Model Pembelajaran Inovatif, Penerbit Media Persada, Medan

Rusaidi, (2009), Pengaruh Model pembelajaran kooperatif tipe STAD terhadap hasil belajar siswa pada materi pokok energi kelas VIII semester II SMP Swasta Madya utama medan T.A. 2008/2009., Skripsi, FMIPA UNIMED

Sagala, H. S., (2012), Konsep dan Makna Pembelajaran untuk Membantu Memecahkan Problematika Belajar dan Mengajar, Penerbit Alfabeta, Bandung

Slameto, (2010), Belajar dan Faktor-Faktor yang Mempengaruhinya, Penerbit Rineka Cipta, Jakarta

Slavin R. E., 2009, Cooperative Learning, Nusa Media, Bandung.

Sudjana.,(2005), Metode Statistika, Tarsito, Bandung. 